\title{
Growing the Green Unknown: Teaching Environmental Literature in Southeastern North Carolina
}

Breaking Ground: A New Course Sprouts

Walking to class, we're still lesson planning. Indeed, although we had thought about and discussed since we were hired in fall 2006 the idea of team-teaching an environmental literature class from the perspectives of our disciplinary specialties (American Indian Studies for Jane, African American literature for Scott), our class still was a work in progress. We were excited on this first day of our brand new course at the University of North Carolina, Pembroke, "Literatures of Ecoliteracy and Environmental Justice," the first ever of its kind here. Despite its evolving character, our collaboration was strong, for we were united in our convictions: respecting our students, their communities, and their heritages; enacting environmental justice; and reconnecting ourselves, our students, and our university to our shared world.

Even now, we remain inspired by the course. It still prompts us to think about our relationships to our environment, especially as we make our home in a place different from where we grew up. What's more, it allowed us to get to know our students in new, more personal ways, as those from Robeson County gave force and shape to the love of their homeland, while those from outside the community-from places as near as the North Carolina foothills and coast, 
as far as Philadelphia and Brooklyn - reflected on their own commitments to Pembroke.

On that first day of class, we decided at the last minute to switch the order of our morning's activities. We opted instead to ask students to write about their views of nature and place, environmental literature, and environmental justice. Then, with those ideas on paper, we would introduce ourselves to each other.

"That'll be more dynamic than starting with another boring syllabus review, don't you think?" Jane asked her chronically agreeable collaborator.

"Absolutely."

This bit of dumb luck became an episode of accidental brilliance, and, as it turned out, one of many accidents that kept this pilot course a vibrant work-in-progress from start to finish. On the blackboard, Scott wrote the questions we had brainstormed earlier: "What does it mean to be 'ecoliterate'? What is 'environmental justice'? What is 'sustainability'? How do people relate to place? What is the relationship between ecoliteracy and environmental justice? What is your place in the world?" The question we really focused on called forth Wendell Berry: "To know who you are, you have to know where you are. Who, and where, are you?" With those questions on the board and our students furiously scribbling, we never made it to the syllabus that morning. Instead, the students' discussion of their place in the world and its relationship to our course themes just popped. These questions, we came to learn, would inspire our students and us even beyond the term of our August to December course.

\section{Up from the Roots: Who and Where We Are}

Who and where we are, are two educators from both sides of the United States and eleven students whose "races" and numbers roughly reflected the triracial demographics of our university. Committed to enacting what bell hooks terms "engaged pedagogy" in Teaching to Transgress: Education as the Practice of Freedom (1994), we wrote with students on the same questions that morning. Because the conversation was so lively; however, not everyone was able to read her or his response in class; consequently, after class we opened our first Blackboard Discussion Board. Jane posted first, to let students to know that she, as a native of California, a San Franciscan for fifteen years, a person composed of oak groves, orange groves, redwoods, and freeways, definitely does not feel "in place" in rural southeastern North Carolina. Born and raised in North Carolina, Scott described 
his relationship to place as a coupling of rural southeastern environmental sensibilities that are his historical inheritance with twenty-first-century consumer culture conveniences. Like our own, our students' relationships to homelands, home places, and the multiple environments we inhabit ranged from a deep connectedness to the natural world to a sense of dislocation from both home and school environments. Addison, a young white man from Robeson County, wrote of his love of nature, because "as an Eagle Scout [he] spent much of [his] time growing up outdoors. Every month [his] troop would take a camping trip to a new location and observe the land and learn to use it in new ways to benefit us, but not harm the environment. Nothing could be more relaxing than a night in the woods surrounded by the warmth of a burning fire" (McMillan 1). Jennie, a young white woman whose home place is Perquimans County, North Carolina, responded to Jane on Blackboard that what the California native had written mirrored her own feelings: "I live about 4 hours from Pembroke, I know some people are from much further, but sometimes because of dialect and the way I see the world I feel out of place with my friends here. Some weeks here are harder for me than others. At home there is that familiarity and the anniversary of some things are really hard for me to handle now that I'm not home" (Harris). Sunshine, half Lumbee and half Italian, was raised in Philadelphia until returning to Pembroke for college; Tamara, an African American mother and grandmother, hailed from New York City before moving to North Carolina at age twenty-one. These women shared with Jane an acute sense of both urban and rural experiences, though neither student had considered the urban landscapes of their childhoods as an "environment" in the stereotypical ways that sandy beaches and fields of wildflowers signal "environment" for many. This cross-section of student expressions of place and space would prove fertile soil for the interplay of ideas our readings generated.

At the close of our first class - which ran slightly over time-our students had already formed bonds with one another; we were energized. As she walked out the door, Tamara smiled and said, "I'm going to love this class. I feel like I've found my niche. I'm gonna tell other people to take it!" Coming across an article in The Chronicle of Higher Education, "Colleges Get Greener in Operations, but Not in Teaching," further invigorated us later that day. The article reported that while colleges nationwide had made tremendous gains in writing sustainability plans, recycling, increasing energy efficiency, xeriscaping, and hiring sustainability managers, they had regressed in infusing environmental sustainability in their curricula. Yet we 
were motivated by the challenges we faced - a campus with a dysfunctional recycling program, a chancellor who believed that water conservation during a drought meant getting water from wells ("Water conservation measures" 1), and only a handful of faculty interested in offering an environmental studies curriculum. For us, it was about more than greening our campus and the courses the university offered, as our scholarship and values are founded on human rights, social justice, and community and planetary health. It's not an overstatement that to us, greening our university's curriculum means life and death, survival and extinction.

As we knew going into the course, Robeson County and southeastern North Carolina-UNCP's primary constituency, the part of the state along and east of Interstate 95-have borne and continue to bear the brunt of multiple disparagements. The region's vulnerability prompted former U.S. Senator Elizabeth Dole to call for the establishment of a "Southeastern Crescent Authority" modeled after the Appalachian Regional Commission:

It is largely rural, and it is significantly poorer. It is in these parts of North Carolina where educational attainment tends to be lower and unemployment rates tend to be higher.... The challenges of globalization have landed smack on the shoulders of the region's textile mill towns, tobacco producing areas, and furniture manufacturing communities. It is also in these parts of North Carolina where the rates of health problems, such as cardiovascular disease, diabetes and obesity, are well above average. Just consider this, if the region east of Interstate 95 in North Carolina were its own state, it would rank 50th in terms of premature mortality....

$[\mathrm{M}] \mathrm{y}$ aim is certainly not to paint a depressing picture of rural North Carolina; rather, I describe this all-too-often overlooked part of my state so that this subcommittee understands the tremendous opportunity that SECA holds for ... areas that while distressed, still hold great promise. ("Dole Touts Bill")

To polluters, the region's social, political, and economic vulnerability makes it seductive. Despite the former senator's condemnation of the region's woes, the kind of economic "investment" that is happening and is slated to happen is not helping the region-all the more important given today's economic recession. The foundations of environmental justice-that environmental degradation happens where the people are least white and least wealthy-holds true for 
this region as well. The list of the region's grievances must start with the explosion, beginning in the mid-1990s, of hog farming, historically attracted Down East because of the state's lax regulations and the region's disempowered, struggling demographics. Today North Carolina ranks No. 2 in the nation in the production of hogs. Those hogs-about 10 million-are concentrated in the eastern half of the state, and the environmental problems they spawn are legion: tons of urine and feces, broken lagoons, gallons of spills, inescapable odor and air pollution, and the severe, widespread diminishment of watersheds, estuaries, and wildlife ("Industrial Hog Operations"). And if factory farms aren't bad enough, the region has faced down the threat of multistate megadumps - at least for now.

It is because of our regional challenges and opportunities that we believed our course would serve critical needs for our students and shared communities. As faculty who work with students of color from Robeson and surrounding counties (areas that are predominantly African and Native American), we can testify to the power of civic engagement and service learning that facilitate campus and community enrichment and privilege the intellectual capital of local students and communities. Likewise, as scholars who take seriously the interpenetrations of place and culture, justice and sustainability, peace and preservation, we believe in the power of restoring not only landscapes but that of restoring people to their landscapes and to each other.

With these as our guiding principles and generous grants from our university's Office of Academic Affairs and Teaching \& Learning Center, we began the pleasurable task of selecting course texts and activities.

\section{Nurturing Growth: What We Read and How We Read It}

The Street by Ann Petry

During registration, many students dropped by or e-mailed to ask us what the course would be about. Their confusion took the form of the following question, roughly speaking: "Environmental literature-is that, like, about that guy who lived in a cabin by some pond and wrote about ants or something?" Our opening readings-the Indigenous Environmental Network's "Native Perspective on WHAT is ENVIRONMENTAL JUSTICE?," the First National People of Color Environmental Leadership Summit's "Principles of Environmental Justice" (1991), the United Church of Christ Racial Justice Commission's Toxic Wastes and Race in the United States: A National 
Report on the Racial and Socio-Economic Characteristics of Communities with Hazardous Waste Sites (1987), and the United Nations' Rio Declaration on Environment and Development (1992) and Declaration on the Rights of Indigenous Peoples (2007)-threw them for a loop. "Where's nature?" seemed to be the simmering tacit question. In these texts, there were no visible puffy white clouds, no audible babbling brooks, and no chirping birds. These introductory readings began productively to unsettle students' preexisting notions of "environment."

Then Ann Petry's The Street (1946) knocked them off their feet. Accepting the African American writer's postwar naturalist novel as "environmental literature" meant accepting some radical propositions: first, that "environment" might be defined as both Thoreau's pond and inner-city New York; second, that one's relationship to one's environment might consist not in dominating one's surroundings, but in being oppressed by them instead; and third, that seeing Petry's Harlem as a community worth fighting for might recast southeastern North Carolina as a region equally worth taking on megadumpers and agribizpigs for. Students' secondary readings for The Street-Michael Bennett's "Anti-Pastoralism, Frederick Douglass, and the Nature of Slavery" (2001), Colin Fisher's "African Americans, Outdoor Recreation, and the 1919 Chicago Race Riot" (2006), and a chapter from Frantz Fanon's Black Skin, White Masks (1952)-solidified these objectives, just as our visit to a nearby farm, Sunset Ranch Organics, owned and managed by Tupac Shakur's mother and stepfather, further deepened our notions of what counts as environment and environmental literature.

Despite their initial shock, students came to understand our reasoning in assigning as the first salvo in our class a book about the inner city, a landscape as tough as the arctic or desert, a geography where trees and open space are reserved for upper-class exurban whites. "I must admit that when I enrolled in this class my first idea of 'Literatures of Ecoliteracy' was writing about nature: trees, flowers, mountains and the like," Grey wrote "I now know, however, that ecoliteracy encompasses so much more. If we maintain that ecoliterate literature is only about nature, or only about people's experiences with the natural world, we alienate people, especially people of color. Not everyone is able to enjoy, or wants to enjoy, nature in the conventional sense" (Sweeney, "Response Paper \#2," 1). To put it mildly, The Street contests "nature in the conventional sense," just as it complicates naturalism in its conventional sense. A naturalist novel like Richard Wright's Native Son (1940), The Street tells the story of Lutie Johnson, an African American wife, single mother, and worker in 
mid-1940s Harlem. A blistering critique in the vein of Frank Norris's 260 The Octopus (1901), Upton Sinclair's The Jungle (1906), and John Steinbeck's The Grapes of Wrath (1937), Petry's novel exposes the city's substandard housing stock, suggests that pollution causes mental and physical defect, likens a shameful education system to a prison, reveals discrimination in healthcare, and confronts workplace misogyny and sexual harassment.

Yet Petry's novel couples a moral worldview to its pervasive ecological grammar. It implicitly criticizes spatial inequalities, in which wealthy white capitalists (embodied by the Chandlers, Lutie's employer) inhabit lush, green landscapes outside the city while a black underclass struggles to survive in a crowded, dirty, polluted ghetto. This inequality expresses itself in parodies of white environmental aesthetics, such as Lutie's ironic appreciation of an inner-city sunset: even as "a blaze of brilliant color ... bathed the street in a glow of light," "a boy fish[ed] through a grating in the street," where "odds and ends had floated down under the sidewalk" $(62-63,65)$. Unlike the wealthy Chandlers' pristine river and the piazza that affords them the view they enjoy, Lutie's is a stream of underground sewage, made inescapable by the sun's piercing rays. As she knows, hers is the neighborhood that takes in the "pigs' feet, hog maw, neck bones, chitterlings, ox tails, tripe... sleazy blouses ... all the bruised rotten fruit and vegetables...the leavings, the sweepings, the impossible unsalable merchandise, the dregs and dross that were reserved especially for Harlem," where its inhabitants survive in spite of, not thanks to, their environment (153). In the lingo of the modern environmental justice movement, The Street narrates the existentialism of "PIBBY" - "place in blacks' backyards," a principle Robert D. Bullard explores in depth in Dumping in Dixie: Race, Class, and Environmental Quality (2000).

Students responded to the novel viscerally, infuriated equally by Lutie's actions (in particular abandoning her son) and the environmental conditions that informed her worldview and curtailed her agency. While racism, classism, and sexism were hardly abstract notions to them, they had not thought before of these forces as "environmental." They were aghast at the myriad ways that racism, classism, and sexism infiltrated and structured the environment, what they had thought of as some sort of neutral playing field, just as they were adamant in extrapolating new concepts of what, after all, "environment" really entailed. Sunshine, for example, invoked Fanon to see the environment as a force that could prompt radical self-revisioning: "Even though they were located in different countries, Lutie Johnson and Fanon both experienced a lot of the 
same prejudice, as they tried to better themselves as young Black people. When people began to put them inside of a box they both found the strength and the means to fight back" (Costanzo, "Response Paper \#2," n.p.)

For Tamara, however, blackness became an environment itself. Quoting Lutie's assertion that "[i]t must be hate that made them wrap all Negroes up in a neat package labeled 'colored'; a package that called for certain kinds of jobs and a special kind of treatment" (Petry 72), Tamara wrote, "[Lutie] questioned her self, her color, and her mental state." That "[Lutie's] determination and motivation was to make enough money to leave the place that she referred to as the 'god-damned street' " saddened Tamara, for it demonstrated the irreconcilable chasm between black experience and black survival in a racist, environmentally unjust structure (White-Chambers 3). The logical end, as Grey wrote, was full retreat from the environment, into one's physical and psychological self, which is its own environment not only for black bodies but for all bodies: "Environment is ... our very own bodies, and ... our very own minds. Our sense of identity is essential to our sense of our environment. If we feel alone or alienated that is an environment we inhabit" (Sweeney, "Response Paper \#2," 1). For us and our students, these definitions of environment-as simultaneously natural, spatial, cultural, social, psychological, and spiritual-compelled hard thinking about social and environmental justice: How do we create a socially just, environmentally sustainable city, as Fisher explores in the 1919 riot of Chicago, when two African American boys swimming in a "white" part of Lake Michigan ignited a white backlash? How do we account for diverse visions of the environment, the legacy of raced, gendered, sexed, and classed histories, as Bennett and Fanon theorize?

As if we needed a counterimage to the counterimage of "environment" provided by The Street, we journeyed past Interstate 95 and its cancer of fast food, gas stations, and motels to Sunset Ranch, a certified organic farm founded by Afeni Shakur-Davis and her husband, Dr. Gust Davis Jr. outside Lumberton. To our minds, Sunset Ranch would tell of an African American woman coming home and reclaiming what might seem to some an irredeemable postindustrial wasteland. We envisioned Shakur-Davis's creation of Sunset Ranch as an uplifting alternative ending to the bleak conclusion of Lutie's story. The farm's biodiversity, and farmworkers Kevin and Cay Hunt's stewardship, excited the senses. "The landscape from the ranch was beautiful," Kristen wrote (Hobbs 3). Sunshine concurred: "It is easy to sense that the land is alive.... When the wind blows, you find yourself overcome with a refreshing calming feeing" 
(Costanzo, "Response Paper \#1," 1). We agreed, enjoying the care the Hunts showed for the farm animals, walking down the perfectly sown rows of arugula just beginning to sprout, and hearing about the Shakur-Davises' plans for the farm's future.

Yet we also wanted our students to consider the full picture: that the farm's produce is shipped nationwide, while localharvest.org (in fall 2008) showed only three farmer's markets and no communitysupported agriculture within twenty-five miles of UNCP; that different histories and negotiated arrangements of race and class (the African American experience of the Shakur-Davises and the Lumbee experience of the Hunts) are worth exploring; and that realities of capital and labor remain thorny as citizens move toward environmentally and economically sustainable agriculture.

While some students confronted these issues in online postings after visiting the farm-Grace, for example, asked, "I wonder if [the Hunts] feel chained to the land in the same way that Lutie dreamed that the super was chained to the building (Petry 191-193)?" (Yusckat 2)-not all of them were ready to shake their faith in the restorative power of country life. Though The Street and Sunset Ranch showed Doug the constraints of his own rural landscape, the siren's song of freedom-of landholding, independence, and selfsufficiency - still obtained. "Since I am able to live in the country I am able to do almost anything without bothering anyone around me," he wrote. "I am able to ride ATVs and hunt when hunting season comes" (Taylor "Response Paper \#1" 2-3). As we would explore in Janisse Ray's The Ecology of a Cracker Childhood (1999), no human being is an island. Rather, as Doug came to realize, "The only constraint ... is too much freedom" (Taylor 3)-and that what seems to be freedom to some is, to someone else, a devastated landscape, a sullied watershed, toxic homelands, and a fractured community.

\section{Ecology of a Cracker Childhood by Janisse Ray}

Our second primary text returned us to a geography more familiar to most of our students: Author-activist Ray's Ecology of a Cracker Childhood is part memoir, part ecological treatise, of the devastation wrought by Euroamerican exploitation of the longleaf pine ecosystems of the southeastern United States, specifically focused on her Baxley, Georgia, hometown. Ray's childhood environmental consciousness was shaped not only by her rural Southern upbringing, but by being raised in the cluttered isolation of her evangelical family's commercial junkyard. Even as a child, Ray understood that this landscape marked her and her siblings as different in undesirable ways. "We knew nobody else lived the way we did, but we didn't 
know how they lived," Ray writes. "We knew they were wasteful and threw perfectly good things in the garbage, which ended up at our house. We thought that meant they were better than we were" (29).

The students loved Ray's honest, heartfelt book, which spoke to their own rural working class experiences. Their passion for Ray's text, and their growing comfort with discussing more complicated understandings of "environment" and "place," resulted in some of our liveliest class discussions, jumpstarted by Scott and Jane's increasingly vigorous intellectual parries.

"You notice that he didn't kill the snake, he just left it and walked away," Jane said one day in class, shortly after we had begun reading Ray. "So he had obviously made some kind of peace with the natural world; he'd developed some compassion for it, maybe after all of the violence he'd already inflicted." She was pleased with her thoughtful interpretation. Gathered around a picnic table near our classroom, under tall pines and a sunny early fall sky, we were discussing the scene in which Ray describes her paternal grandfather being called by his adult son, Ray's father, to see the huge snake he had discovered behind his father's refrigerator:

Daddy said the snake, coiled up, would fill a hubcap. "If you butchered him out you could eat for three months," he said. It was dim behind the refrigerator, with the electricity already turned off in the house, and he couldn't tell what kind of snake it was. It looked like a rattlesnake.

Grandpa peered around, kind of grunted, said "I reckon it is," and ambled back into the front room with no more concern than a mailbox. (59)

But Scott disagreed with Jane's interpretation that the Ray patriarch could feel any kind of peace with the natural world. "Not a chance," he said.

"Why not?" Jane asked.

"The way I see it, that's the grandfather's way of demonstrating his power," Scott replied. "His power over women, his power over his son, who doesn't really hunt or fish; his way of allying himself as the end-all, be-all predator. He's someone who's obviously comfortable with being threatened, because he can threaten right back. He doesn't give a damn what anybody thinks. He doesn't kill the snake because it's a way of reinscribing his power over his environment: of not killing when he could, of leaving a deadly snake in a space where it might hurt his family members. It's sort of a middle finger to society." 
"What!" Jane said, shocked. "No way!"

The students started laughing.

Jane put down her book. "No, seriously," she said, "he could easily have killed the snake, but he chose to let it live. I really think Ray is trying to point out that despite this man's consistent violence toward other people and toward the environment, he still has great affection for the natural world. People are complicated! I mean, look on page... oh, where's the part where she describes what her grandfather is like?"

The students flipped through Ray's "Iron John" chapter until Sunshine said, "Page forty? Where she's talking about him being violent?"

"Yeah, there! Thanks, Sunshine. And-oh! OK, up even a little farther, the part about the woods...." Jane read: "Because he withdrew often to the woods for safety and comfort and for shelter and food, he knew them like nobody I've ever known. All his life he never loved a human the way he cherished woods; he never gave his heart so fully as to those peaceful wildland refuges that accepted without question any and all of their kind" (40).

"Yeah, but-" Scott began.

"No wait, just one more part, the one Sunshine pointed out," Jane said. "She goes on to describe how violent he is with humans, that he was 'terrifying, prone to violence and unmerited punishment that caught you unawares'" (40).

"And that her dad never wanted to get caught alone with him when he was a kid," Lynsey added.

"Yes, exactly!"

"But that just supports my point," Scott exclaimed. "That he'll brutalize anyone or anything at will!"

"Yes, but because he doesn't choose to kill the snake here," Jane argued, "doesn't that demonstrate that even this brutal man has a warm spot in him for the creatures of the natural world?"

"Yes!" said Tamara.

"No!" said Grey.

The students started laughing.

And so we continued, this kind of dynamic lit-crit we both loved, modeling to students a number of important ideas about the value of close reading and the possibilities of creative, well founded, expansive literary analysis. Why did this debate over not killing a rattlesnake matter? Pedagogically, it mattered because students were fixated for almost an entire class period on the details of Ray's text and how those details made meaning. They saw that interpretations-ways of seeing the world, literally and 
figuratively-mattered, and they hurried to plumb the text for evidence to support or refute the position of the professor or classmate they agreed with, or to promote their own different interpretation.

In building these interpretations of the text, students were simultaneously, if unknowingly, developing critical interpretive and communicative skills that would provide real-world currency in environmental movements-especially as they began to see that their ecoliteracies, their knowledges of their homelands forged in uniquely raced, classed, sexed, and gendered contexts, might compel new kinds of green coalitions. These discussions (and their reading of supplemental essays by Lawrence Buell, Winona LaDuke, and Vandana Shiva) forced students to transgress cultural and political boundaries to make connections that would help them make sense of, and deepen a sense of responsibility for, their own local environments in relation to global ecosystems, from understanding the environmental impacts of drilling in the Arctic National Wildlife Refuge to comprehending one's hometown of Fairmont, North Carolina, as an equally significant ecosystem.

Our discussions of the text segued into our in-person visit from Ray, two weeks before Barack Obama's historic election. Ray had been busy helping to register voters in her community, work that put her in contact with community stories of hardship and privation. "Everywhere I look the world is wounded," Ray told our class, ticking off examples of racism, poverty, skyrocketing gasoline prices, and the Iraq War. The stories Ray told were compounded by the environmental devastation that Appling County, where Baxley is located, continues to suffer, a devastation of natural and human communities that drives many residents from the county. Doug queried her on her difficult relationship to her father, which she outlines in her text, and Brooklyn-born Tamara commiserated with Ray on the eternally fierce call of home, even a home that seems to outsiders to be damaged and broken. Our relationship to our home places can be mixed, Ray concurred, a compulsion to flee against the inescapable sense of the place that is hardwired within our bodies, and the loyalty to our families who remain in those places. Too often, Ray believes, we give ours best selves, our best years, to somewhere other than our home communities.

Ray's personal warmth and generosity caused our students to fall in love with her. Most had never had a published author speak with them personally in a class, especially one whose life experiences paralleled their own. "I believe place matters to us, as people," she told us. "My bones are made from south Georgia. If we all abandon these 
places we're from, it spells doom for those places-cultural doom, ecological doom." Both in class and later that day at a public lecture, Ray encouraged us all "to knock on people's doors, talk to our neighbors, join our community gardens, with the full understanding that we will not share a common environmental consciousness, only fragments of convergence, but these are stepping stones toward conversation and revision and action."

\section{Whispering in Shadows by Jeannette Armstrong}

Our third primary text illustrated well the forms of environmental activisms Ray had outlined, that individuals might employ locally and globally. While Indigenous literatures in general remain vastly understudied and minimally taught in mainstream university environmental literature courses in the United States, Whispering in Shadows, by Syilx (Okanagan) community activist and author Jeannette C. Armstrong, rarely appears in U.S. higher-ed curricula even in American Indian literature courses. It was essential that Indigenous worldviews toward what Westerners term "the environment" - not some alien, disembodied context, as Westerners see it, but a total experience Native peoples view as an ongoing interaction with their relatives in the plant, animal, mineral, and element worlds-figure prominently in our course. Our strategy in selecting Armstrong's novel reinforced multiple themes that we had already discussed, and introduced re-thinking some of these same themes from alternative perspectives.

By positioning Whispering in Shadows as the final primary text of our course rather than placing it at the beginning, we sought to work against mainstream determinist notions of Indians as original inhabitants of a pristine environment (often called "wilderness") who gradually disappear into the mists of history with the advent of colonial contact. Armstrong's novel depicts an active, vital twenty-first-century Okanagan community whose members engage in a range of activities on their home reserve, in urban spaces, and throughout the so-called Americas. These Natives have simultaneously maintained ancestral traditions and connections to the original teachings of their people even as many have internalized aspects of colonization's legacy that result in community dysfunctions, including substance abuse and abandoning traditional foodways for the convenience of a fast food diet. In other words, Armstrong's characters are real human beings who illustrate a range of perspectives on negotiating pre-colonial Syilx traditional practices and contemporary experiences in maintaining balanced relationships with the earth. 
While Armstrong's novel outlines traditional practices of respectful reciprocity in Okanagan interactions with the natural world, her story also focuses heavily on the violent disruptions that the imperial project has inflicted upon the earth and its Indigenous inhabitants. Armstrong juxtaposes Penny's memories of loving, collaborative engagement with the natural world, through the Okanagan language (which, like all Indigenous languages, has developed in relation to specific homelands) and activities such as harvesting berries and camas with Penny's female relatives, against grisly scenes of the effects of the North American Free Trade Agreement, military occupation of Indigenous homelands in Mexico, and Penny's toxic wagelabor experience picking apples in the Okanagan (a job later linked to Penny's developing cancer). Armstrong's Indigenous depiction of humans' complex relationship with the natural world demands non-Indigenous consideration of "the environment" as a fabric of inextricably interwoven systems that are not outside of human beings, but that are embodied by humans, a concept our class first considered while reading Petry's The Street. If environments are not respected and nurtured, the health and respect of human bodies and communities cannot be expected to endure.

Yet Armstrong's novel expands the concept of human body as "environment" from one of individuality to that of collectivity. "I've been thinking about us, the human, as 'natural environment,' too," Penny writes in a letter to her non-Native college friend, Julie. "Aren't we? I don't mean as individuals. I mean the body human. How is the human organism, as one whole unit, faring in what it has wrought?" Penny observes to Julie the number of "[h]ealing workshops springing up everywhere," workshops focusing on human and environmental healing, and tells Julie that she heard one American woman "[speak] about being wounded by technology" (84). By interlacing Penny's diary entries, personal letters, interior monologues, poetry, Coyote stories, memories, and activities, the structure of Armstrong's novel creates a unified fabric encouraging a holistic view of global environments, which include human beings, to counterbalance the fragmentation created by neocolonialism's environmental devastation.

The powerful notion of environmental stewardship that emerges from personal responsibility based on the rights of all members of the natural world-from stones, to water, to turtles, to wind-was another radical concept to the majority of our students. Armstrong's text represents an Indigenous worldview toward homelands and other natural spaces that insists upon their healthy maintenance for their own sake, rather than for how these environments can serve 
humans as resources. To help our students contextualize this concept, we assigned several of Armstrong's nonfiction essays: "Let Us Begin with Courage," "Sharing One Skin," and "En'owkin: Decision-making as if Sustainability Mattered." In these essays, Armstrong more explicitly articulates a number of Okanagan beliefs about community process and how it arises from the original instructions embedded in Okanagan language and lands. Responding to "Sharing One Skin," Sunshine wrote:

Armstrong consistently says that she, and her people, [are] nothing without the Land... But it is not just any area of land found in a city block or city park, rather from the land in which her ancestors are from, a land shared by those within her community. It is through the interconnectedness of the individual + family + community + land that this life saving formula is found. "I fear this because I know that without my land and my people I am not alive. I am flesh waiting to die." ("Sharing One Skin")....

[I]t is easy to see why Penny, the main character of her novel, emerges [as a] Native environmentalist (Costanzo, “Response Paper \#5,” 1-2)

Doug also found a powerful message in Armstrong's novel, one that complicated his assertion earlier in the course that "[t]he only constraint [in nature] is that there is too much freedom" (Taylor, "Response Paper \#1," 3). Indigenous worldviews toward the natural world do not focus on the concept of "freedom," but on longstanding beliefs in respectful relationships that foster ecological, cultural, and spiritual sustainability. "Armstrong made everything clear by explaining how her tribe deals with environmental problems and their beliefs," Doug wrote in his final response paper: "I really believe this concept mainly because we as individuals make decisions that can affect every aspect of life. For example, if we as a society continue to pollute the environment then we will also continue [to] aid global warming and destroy the ozone layer. If we do that then we, basically, will be living on an island surrounded by water because of the ice caps melting" (Taylor, "Response Paper \#5," 1-2). Doug's ice caps metaphor recognizes the sort of "no person is an island" environmental and social justice theme that, in myriad forms throughout the semester, we hoped our students would consider more deeply. As we approached the semester's end, we also strove to create culminating assignments that would allow students to reflect on their enhanced environmental understandings, and take these understanding with 
them as they interact with family, friends, home places, and international spaces. Such encompassing awarenesses of the meshwork of systems that create healthy biodiversity are at the heart of global Indigenous worldviews.

Underscoring the dynamic interconnections of all peoples and environments, and proving that individuals can change the world, Dollie Burwell, the founder of the U.S. environmental justice movement, visited Pembroke in early November and inspired our class with her story of Warren County, North Carolina's fight against a PCB dump. After a private company illegally disposed of the chemical alongside nearly two hundred miles of roads across North Carolina, the state chose predominantly poor, predominantly African American Warren County as its dumping ground-despite the site's environmental unsuitability. "The state thought we didn't know PCBs from Dr. Pepper," Burwell told our class. But the African American, American Indian, and white residents of Warren County joined together and showed the state otherwise in fall 1982. "Local community members should make decisions about their community environment," Burwell said, as the incipient environmental justice movement showed the urgency of interracial cooperation and the immorality of outsourcing toxicity and pollution to less powerful communities.

As images of children wearing gas masks, marchers carrying signs and shaking their fists at state highway patrolmen, and protesters laying their bodies on the asphalt to stop the PCB-laden dump trucks flashed on the screen behind her, Burwell emphasized that you have to fight for the world you will hand over to your children and grandchildren. Though the Warren County protesters did not stop the dump, they did extract from the state the promise to clean the site, a promise kept in 2004. "You have to let people see there was life on that site," Burwell said, thankful that deer and wild turkey have returned. As someone who also was a critical force behind President Obama's southeastern campaign, Burwell continued to demonstrate the power of individual activism. She emphasized that it's up to each one of us to make the change we want to see. "The movement is not hard to start," she said. "If you stand up and have passion for what you believe in, people will follow" (fig. 1).

\section{Harvesting a Legacy: Sustaining Our Engagement}

Although we relished our activities inside and outside class, we never wanted the understandings provoked by the course to remain merely academic exercises for our students. Instead, the subject 


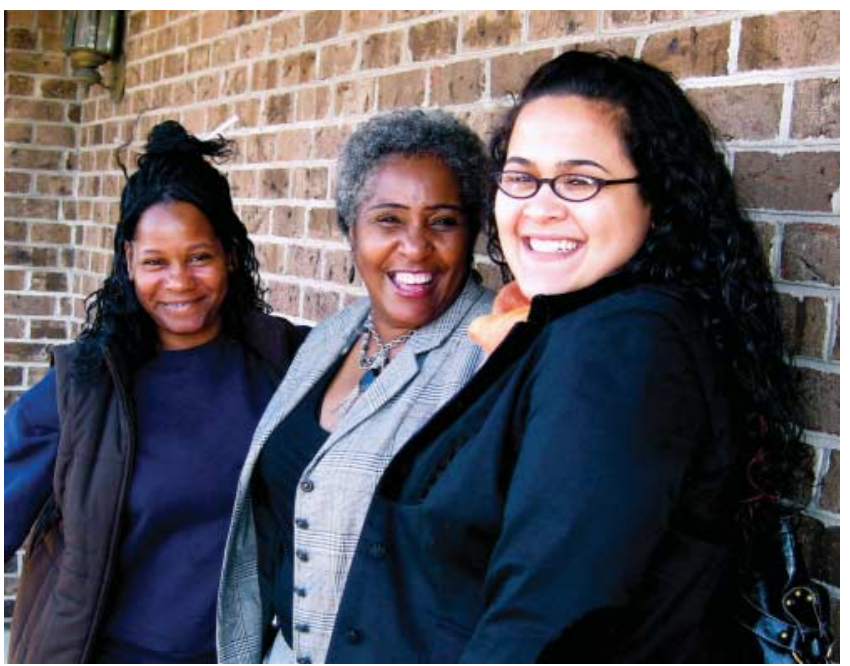

Fig. 1: Students Tamara White-Chambers, left, and Sunshine Mardella Costanzo, right, were pleased to meet environmental justice founder Dollie Q2, Q4 Burwell, center. (Photograph by Jane Haladay.)

demanded that we work to bring our knowledge to the wider world and to learn as much from living experts as we had from texts and films. From a panel four of our students led at the Association for the Advancement of Sustainability in Higher Education's annual convention, to a collection of environmental oral histories, to multimedia presentations about local flora and fauna, our activities and assignments sought to empower our students to engage: to engage not only with texts, each other, and us, but with environmental and social justice advocates, our campus neighbors, and our regional-increasingly global-communities.

AASHE's 2008 conference, held in Raleigh, NC, gave four of our students-Jennie, Desirée, Grey, and Tamara-the chance to engage higher education's visions of environmental justice, as well as to connect with other faculty and student activists. Moved by Vandana Shiva's keynote address exposing the irrevocable global interconnections of transnational agribusiness and intrigued by the dozens of green products and services available to campuses, our students nonetheless had the feeling of being outsiders at this event. Unlike other student participants, they weren't at AASHE because they were a part of an environmentalist group; Desirée and Tamara realized that they were two of very few participants of color. Yet the standing-room-only turnout for our students' panel, and the 
questions they fielded after their papers, showed them that their selfperceived "difference" - and the differences in the way they engaged environmentalism and sustainability-was the very knowledge sought by many of the conventioneers who lacked the UNCP students' experiences. After their presentation, several members of the audience came up to thank them for sharing their stories. Some audience members invited them to join regional eco-advocacy groups with global engagements, such as the Southeast Youth Food Activism Summit and Real Food Challenge; an Americorps Volunteer in Service to America stationed at Berea College recommended bell hooks's newest book, Belonging: A Culture of Place (2008). And Michael B. Smith, assistant professor of history at Ithaca College, commended the four students "for addressing the social justice dimension of sustainability in a way few other panels or speakers [at AASHE] did" (fig. 2).

The students' midterm assignment invited them to engage their home communities and families on issues of ecoliteracy through the collection of environmental oral histories. Talking with their relatives, neighbors, even friends from their dorm, gave all of us new

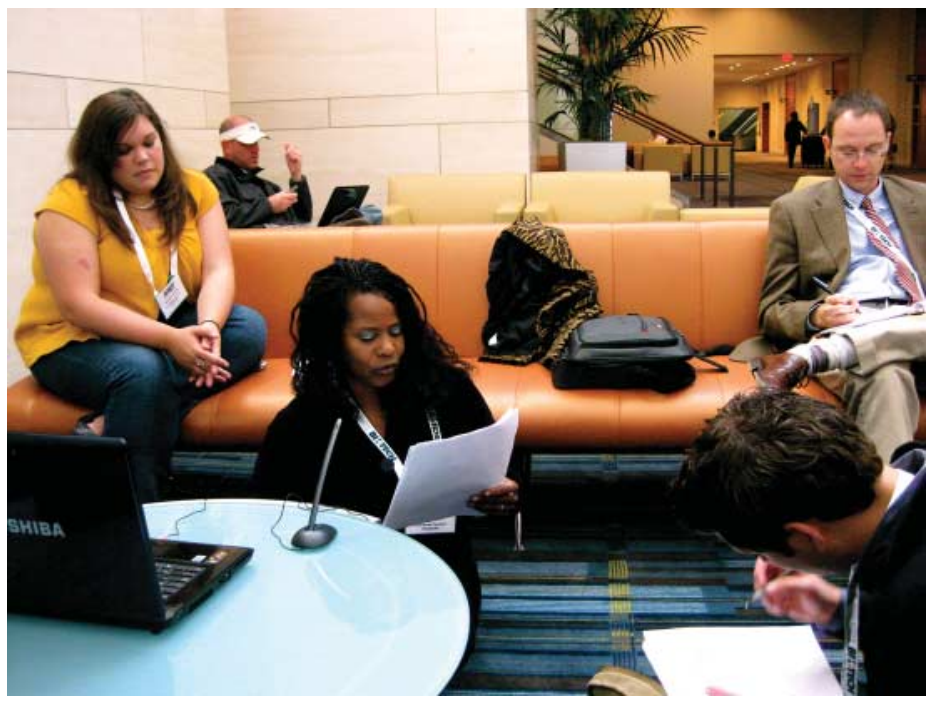

Fig. 2: Students Jennie Harris, White-Chambers, and Grey Sweeney, from left, prepare for their presentations at the 2008 conference of the Association for the Advancement of Sustainability in Higher Education at the Raleigh, Q4 NC, convention center, as Professor Scott Hicks listens (right). (Photograph by Jane Haladay.) 
understandings of local ecoliteracies and deeper appreciations of the importance of environmentally and socially just ways of living with other people in a shared place. Doug's father, born and raised in Robeson County, reminisced about "play[ing] in the woods. I guess you don't do that these days, but we had some vines from trees and we would swing from tree to tree playing Tarzan." Taylor went on to lament the end of spring and fall, thanks to now-frequent 90-plus-degree days in March and September, and called on people to be more careful: "We maybe already have done too much, and I don't know if we can turn it around or not."

Students' environmental oral histories evidence the curiosity and respect the majority of the students brought to the assignment. We were happy that students' oral histories created an archive that shed new light on literary, political, and international cultural frameworks and theories we studied in class; we were happier still to witness the students' renewed appreciation for and engagement with the regional landscapes we inhabit and the people who are stewards of these environments.

As the semester drew to a close, we understood the importance of fortifying ourselves by acknowledging our shared community of comrades and supporters, so that we might continue to engage these crucial issues together once the class was over. Thus our final assignment was a celebration, a potluck "community feast" instead of a final exam, held in the university's Multicultural Center. Students invited their environmental oral history interviewees to attend, and we were honored to welcome Addison's grandmother, who treated us to a homemade pecan pie. While we filled our stomachs with Robeson County field peas, chicken and rice, and even kudzu (Lynsey's treat), students gave presentations on local flora and fauna. With their presentations over, we traded recipes and ideas about the changes we wanted the university cafeteria to make and what we each could do to stop global warming. Our feast, we soon saw, was both culmination and initiation.

In the end, we are proud of our students, our class, what we left behind, and the optimism we have for the future. To mark the conclusion of our course, we planted a pin oak tree one gray December day during finals week; our tree thrives outside Scott's office window. We are happy to hear that UNCP's nascent recycling program is making major progress, diverting about seven tons from landfills in April 2009 alone ("Campus recycling" 10). The same month, two years after we began planning this course, we won final approval for a permanent General Education course, ENG 2410, titled "Environmental Literature." While a minority of sciences faculty 
wanted to protect their turf from humanities faculty when the discussion of an interdisciplinary environmental literature course arose, we appreciated the support of biology professor Lisa Kelly. She wrote that she was "excited that students in the humanities will be challenged to investigate environmental issues, and the value of ecosystems and species to literature, culture, and history" and added that she would encourage students to enroll in the course (fig. 3).

As we reflect on what we and our students taught each other, we feel honored that we participated in an act of environmental thoughtfulness on our campus that we hope continues to multiply. We hoped to offer students the tools and knowledge to become "ecoliterate" empowered with "comprehension of ecology, human ecology, and the concepts of sustainability, as well as the wherewithal to solve problems" (Orr) - in a world where environmental threats demand new consciousness and urgent action. While it isn't possible to assess the long-term effects of our course on changes in our students' thinking and behaviors concerning environmental and social justice, their

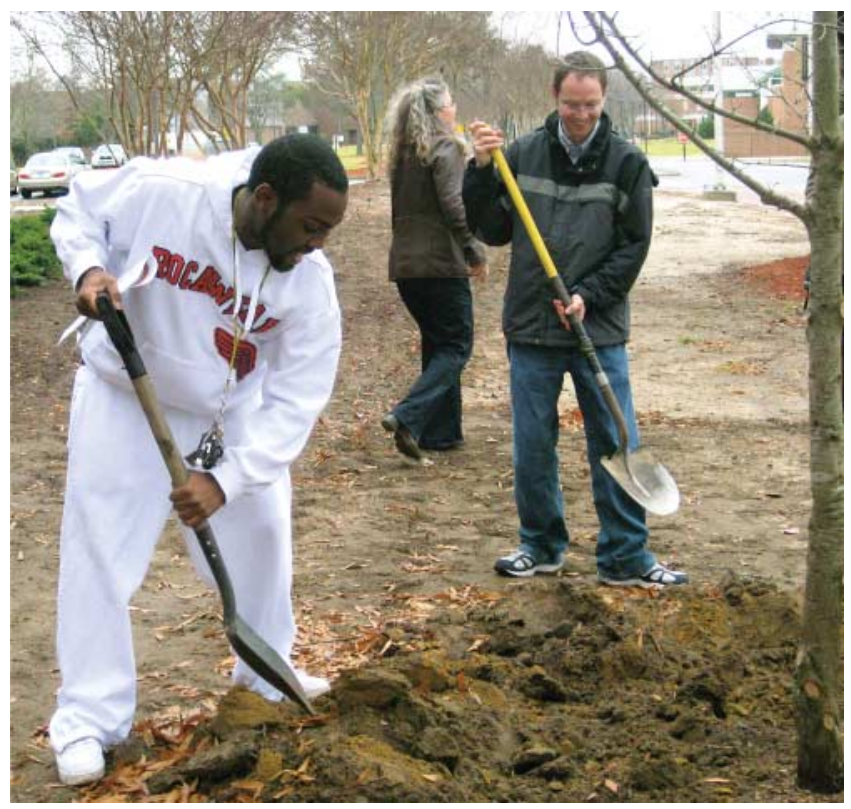

Fig. 3: Student J. J. Welch, left, and Hicks, right, shovel dirt on the tree our class planted as a semester's-end commemoration. Professor Jane Haladay, Q4 center, welcomes faculty, staff, and students to the ceremony. (Photograph by Jane Haladay.) 
end-of-course evaluations suggest that they will not view "the environment" and personal relationships to place the way they did before they enrolled in AISS/ENGS 2111. We residents must reclaim southeastern North Carolina from agribusiness and landfills. We must work to recuperate traditional knowledges and ecological heritages. And we must value all community members and the environmental memories they safeguard and share. Put another way, we must find and put into everyday action an environmentally just way of speaking of, with, and for nature. Our class, we hope, was a small but meaningful step down that road, whether asphalt or red earth.

\section{W ORKS CITE D}

Armstrong, Jeannette. Whispering in Shadows. Penticton: Theytus, 2000.

—. "En'owkin: Decision-making as if Sustainability Mattered." Ecological Literacy: Educating Our Children for a Sustainable World. San Francisco: Sierra Club Books, 2005. 11-17.

_ . "Let Us Begin with Courage." Center for Ecoliteracy. Web. August 19, 2009.

- "Sharing One Skin: Native Canadian Jeannette Armstrong Explains How the Global Economy Robs Us of Our Full Humanity." New Internationalist. FindArticles.com. Web. August 19, 2009.

Bennett, Michael. "Anti-Pastoralism, Frederick Douglass, and the Nature of Slavery." Beyond Nature Writing: Expanding the Boundaries of Ecocriticism.

Ed. Kathleen R. Wallace, and Karla Armbruster. Charlottesville: U P of Virginia, 2001. 195-210.

Buell, Lawrence. Writing for an Endangered World: Literature, Culture, and Environment in the U.S. and Beyond. Cambridge, MA: Belknap P of Harvard U P, 2001.

Bullard, Robert D. Dumping in Dixie: Race, Class, and Environmental Quality. 3rd ed. Boulder: Westview Press, 2000.

Burwell, Dollie. “The Warren County Story: Environmental Justice Comes Full Circle." U of North Carolina, Pembroke. November 6, 2008. Lecture.

"Campus Recycling Grew by 44 Percent in April." Brave Bulletin 10.19 (1 June 2009): 9-10. Web.

Carlson, Scott. "Colleges Get Greener in Operations, but Not in Teaching." The Chronicle of Higher Education. Web. August 21, 2008.

Costanzo, Sunshine Mardella. “Response Paper \#1." N.d.

—. "Response Paper \#2." October 1, 2008.

- "Response Paper \#5." N.d.

"Dole Touts Bill to Remedy Economic Distress in North Carolina and Southeast." Press release.

Elizabeth Dole-U.S. Senator for North Carolina. N.d. Web. May 3, 2007.

Fanon, Frantz. Black Skin, White Masks. 1952. Trans. Charles Markmann. New York: Grove, 1994. 
Fisher, Colin. "African Americans, Outdoor Recreation, and the 1919 Chicago Race Riot." To Love the Wind and the Rain: African Americans and Environmental History. Ed. Dianne D. Glave, and Mark Stoll. Pittsburgh: U of Pittsburgh P, 2006. 63-76.

Harris, Jennifer. "RE: Who and Where We Are: Place \& Belonging." Literatures of Ecoliteracy \& Environmental Justice Discussion Board. Blackboard, 2008. Web. September 1, 2008.

Hobbs, Kristen. "Response Paper \#1." N.d.

Hooks, Bell. Teaching to Transgress: Education as the Practice of Freedom. New York: Routledge, 1994.

"Industrial Hog Operations: The Overview." N.C. Chapter, Sierra Club. N.d. Web. May 25, 2007.

Kelly, Lisa. Letter to Michael Alewine, Chair, General Education Subcommittee, U of North Carolina, Pembroke. February 16, 2009.

LaDuke, Winona. "Food as Medicine: The Recovery of Traditional Foods to Heal the People." Recovering the Sacred: The Power of Naming and Claiming. Cambridge: South End, 2005.

McMillan, Addison. “Response Paper \#2." September 30, 2008.

"Native Perspective on WHAT is ENVIRONMENTAL JUSTICE?" Indigenous Environmental Network. N.d. Web. August 7, 2009.

Orr, David W. “Ecological Design Intelligence." Center for Ecoliteracy. 20052009. Web. August 11, 2009. Rpt. “The Learning Curve.” Resurgence 226 (September/October 2004).

Petry, Ann. The Street. Boston: Houghton Mifflin Company, 1946.

"Principles of Environmental Justice." Environmental Justice Resource Center, Clark Atlanta U. October 27, 1991. Web. August 7, 2009.

Ray, Janisse. Ecology of a Cracker Childhood. Minneapolis: Milkweed Editions, 1999.

__. "Radical Sustainability." Mary Livermore Library, U of North Carolina, Pembroke. October 23, 2008. Lecture.

—. Class Lecture. U of North Carolina, Pembroke. October 23, 2008.

Rio Declaration on Environment and Development. Environment for Development. United Nations Environment Programme. June 3-14, 1992. Web. August 7, 2009.

Shiva, Vandana. "Science, Nature, and Gender."

Smith, Michael. "AASHE and Social Justice." Message to Jane Haladay. November 17, 2008. E-mail.

Sweeney, Grey. "Response Paper \#2." September 27, 2008.

Taylor, Doug. "Response Paper \#1." September 11, 2008.

- . "Response Paper \#5." November 26, 2008.

Taylor, Paul Douglas. Personal Interview by Doug Taylor. October 31, 2008.

Toxic Wastes and Race in the United States: A National Report on the Racial and Socio-Economic Characteristics of Communities with Hazardous Waste Sites. United Church of Christ. Commission for Racial Justice. 1987. Web. August 11, 2009.

United Nations Declaration on the Rights of Indigenous Peoples. United Nations. September 13, 2007. Web. August 7, 2009. 
"Water Conservation Measures Implemented Across Campus." The Brave Bulletin 9.8 (2007): 1.

White-Chambers, Tamara. "The Streets." Response Paper 1. September 11, 2008.

Yusckat, Grace. “Response Paper \#1.” N.d. 